\title{
Stimulation of investment processes in renewable energy sector
}

\author{
Nataliia Savina ${ }^{1}$, Yevheniia Sribna ${ }^{1, *}$, Volodymyr Yemelyanov $^{2}$, Svitlana Dombrovska ${ }^{3}$, and \\ Dmytro Mishchenko ${ }^{4}$ \\ ${ }^{1}$ National University of Water and Environmental Engineering, 11 Soborna, 33000, Rivne, Ukraine \\ ${ }^{2}$ Petro Mohyla Black Sea National University, 68 Paratroopers Str., 54000 Nikolaev, Ukraine \\ ${ }^{3}$ National University of Civil Defense of Ukraine, 94 Chernyshevskaya Str., 61023 Kharkiv, Ukraine \\ ${ }^{4}$ University of Customs and Finance, 2/4 Vladimir Vernadsky, 49000 Dnipro, Ukraine
}

\begin{abstract}
The purpose of the article is to assess the pace of capital contribution and investment in solar energy in order to increase the energy security of national economies. The study analyzes the development of the global solar industry for years 2009-2019 in the context of investment support. The main stages of development of world solar energy are marked and the priority of countries and regions is determined. Factors of attractiveness of solar energy for private investment are noted, namely the investment climate is formed at the expense of legislative maintenance of this sphere, and in the economic plan at the expense of introduction of the «green» tariff. Two main investment processes in the development of solar energy are noted. First, these are large private companies that implement large-scale projects from solar stations. Secondly, this small private investment to provide electric for households that identified a small city urbanization and climatic conditions. It was found that the solar energy market depends more on capital intensity than on resource intensity. The result of economic calculation is indicated, which allowed to determine the term of reduction of the cost price of $1 \mathrm{~kW}$ of photovoltaic power station electricity to the level of NPP production cost for ten years.
\end{abstract}

\section{Introduction}

Interest in the development of renewable energy can be traced in all countries of the world from highly developed to backward in economic development. The macroeconomic importance of renewable energy in the formation of the share of GDP is constantly growing. With the development of this energy, the demand for relevant technologies and equipment is growing accordingly. Among the types of renewable energy, a significant share is occupied by solar energy, which is actively developing in two directions: in business and as an additional source of relatively cheap electricity for households and individual enterprises.

\footnotetext{
*Corresponding author: e.v.sribna@nuwm.edu.ua
} 
The growth of primary electricity consumption and the tendency to reduce its production from hydrocarbon sources in combination with increasing anthropogenic pressure on the environment is forcing countries to reconsider their energy security policies and focus more on solar and wind power generation. Accordingly, the dynamic development of solar energy and the introduction of innovative technologies indicate the importance of solar power plants.

The purpose of the article is to assess the pace of capital contribution and investment in solar energy in order to increase the energy security of national economies.

\section{Methods}

Realization of the purpose of research provides involvement of such methods: systematization, summarization of the latest scientific publications and statistics published by governments and accountable organizations on the financing of global solar energy; method of comparative analysis to compare investment in solar energy with other types of renewable energy; system and logical analysis, method of information synthesis; quantitative method; analysis of the legal framework of the world's leading countries for the regulation of solar energy; study the specific experience of the countries that demonstrate successes in investing in solar energy. The principle of interdisciplinary is widely used in the article: through the analysis of legal mechanisms the influence of financial is revealed regulation of solar energy.

\section{Results and discussion}

According to the analytical report RN21 (Renewable Energy Policy Network for the 21st Century) by 2020, the dynamics of increasing solar energy powerful enough. In 2009, the total production of solar energy was $23 \mathrm{GW}$, and at the end of 2019 the total production was $627 \mathrm{GW}$. This marked an annual increase in production of solar energy more than $100 \mathrm{MW}$ [1].

While until 2012 the production of solar generation was carried out mainly by Germany, Japan and the United States, since 2013 India and China have joined. Thus, in terms of national economies, China has become a world leader in the introduction of photovoltaic solar systems in energy since 2015 [2]. As of 2019, China, the United States, Japan, Germany and India have become the main leaders in increasing the potential for solar electricity production. Accordingly, the structure of the global increase in solar photovoltaic capacity has the following trend: the share of China is $26 \%$, the United States accounts for $12 \%$, India - $9 \%$. $27 \%$ of the world's solar energy production capacity is formed by two groups of countries the first group: the total capacity of Japan (6\%), Vietnam (4\%), Spain (4\%), Germany (3\%), Australia (3\%), Ukraine and South Korea (3\%); the second group of countries - all other countries in the world [3].

The global capacity of solar thermal energy in the period 2009-2019 was formed by the following countries: 1.6 GW - USA, 2.4 GW - Spain, $2.2 \mathrm{GW}$ - other countries (mainly China, Israel, South Africa, Kuwait), which put into operation new plants for the production of components for solar power plants. This segment was led by Israel. The second position is occupied by China, South Africa, and the third - France and Kuwait [4]. In addition, Israel, Kuwait and France began implementing a new CSP technology that was established and commercialized in the 1980s. Since 2019, Spain and the United States have initiated the implementation of projects based on a parabolic gutter outside their borders using an automated control system via the Internet. All these initiatives have increased global capacity by $11 \%$, for a total of $6.2 \mathrm{GW}$ at the end of 2019 . 
If previously the use of PPS was considered quite expensive, and their implementation was limited, mainly in areas of sunlight (the most potential niches of the market), since 2017 the situation has changed. This happened due to a number of factors:

- The growth of innovative solutions in energy storage (batteries have become more efficient and affordable). In 2010, the price of ion-cast batteries decreased by $80 \%$.

- Implementation and innovative developments have reduced the instability of solar energy production and increased the reliability of these stations.

- Reducing subsidies for the cost of megawatt-hours of electricity. For the period of 2020, the rate of non-subsidization of the standard cost of solar energy is 43-53 dollars per $1 \mathrm{MWh}$, which is lower than the cost of natural gas, which costs 42.78 dollars per $1 \mathrm{MWh}$ [5].

This means that in the markets of China, Germany, Britain, India, USA, Japan, solar energy has reached price parity with traditional generations [6]. For Japan, the cost of solar energy remains the highest in the world. This is due to high capital expenditures. However, in the $20 \mathrm{~s}$ and $30 \mathrm{~s}$, the cost will be reduced due to the transition of the country to purchase electricity through competitive energy auctions.

The highest prices for solar electricity in the world are in Africa due to high investment costs, and the lowest in Australia due to the widespread use of home solar power plants. In addition, the specificity of the Australian market is that the number of private and commercial stations located on the roofs exceeds the number of large PPS.

Over the past ten years, the regulatory cost of electricity for large photovoltaic power plants has decreased by an average of $86 \%$ [7]. However, there is still a technical problem for solar stations - the energy storage complex, which reduces the efficiency of these stations. Therefore, in technological terms, solar stations are implemented as a complex «object + storage».

Thus, due to innovative implementations in the production of components for PPS and organizational solutions during construction and operation - all this has allowed to achieve network efficiency parity of large solar stations. For household stations, such parity has not yet been achieved. In almost all world markets that are leaders in solar energy, with the exception of India, network parity of commercial PPS has been achieved.

The technical problem of connecting the PPS to the existing grid was slowed down due to the problem of balancing the network load. However, these contradictions are resolved through organizational and technical measures. For example, in China and India, CHPs are being modernized to produce heat without using electricity. In addition, coal and steam power plants are being improved to create greater flexibility and stability of the entire power system. Another measure is the tool of creating energy associations with neighboring markets (countries). This is typical of some regions of the United States and Northern Europe.

Practice shows that solar stations reduce tariffs during the day and wind - at night. In addition, the German and Danish power grids were integrated with each other, which ensured their high reliability compared to other countries.

The specificity of the world market of renewable energy is the formation of intelligent inverters, which allow the distribution of local energy resources in network assets with minimal impact on electricity consumption. This is legally established in the provinces of Quebec, as well as system services are being implemented in Italy and a new market for services is being formed in the United Kingdom.

Introduction of innovative technologies through automation, artificial intelligence, blockchain; the use of new components of stations - all this stimulated the further development of solar energy, which significantly reduces the financial and time costs for the operation of PPS, and consequently for the production of electricity. Thus, the company Firest Solar [8] due to the transformation of the energy process at the station has reduced the cost of electricity production by $30 \%$. 
Artificial intelligence technology allows solar stations to reduce errors in daily weather forecasting, which allows blockchain to manage stations more efficiently and overcome bureaucratic problems. Increasing demand for solar energy is a trend towards the formation of so-called large smart cities. Smartcity is a city with a population of over 1 million people, which has a renewable energy infrastructure, saturated mainly with solar and wind stations. Currently, there are 10 such cities in the world and two zero-cycle cities are planned. In particular, it is planned to invest \$ 500 billion in the construction of the city of Queyside in Saudi Arabia [9] (table 1).

Table 1. Use of renewable energy in smart cities.

\begin{tabular}{|c|c|c|c|}
\hline City & Country & $\begin{array}{c}\text { Population, } \\
\text { million } \\
\text { people }\end{array}$ & $\begin{array}{c}\text { The share of solar and wind energy } \\
\text { in the total amount of electricity } \\
\text { generated during the year }\end{array}$ \\
\hline \multicolumn{4}{|c|}{ Working } \\
\hline San Diego & USA & 1,4 & 33 \\
\hline Los Angeles & USA & 1 & 20 \\
\hline Jaipur & India & 3 & 20 \\
\hline Hamburg & Germany & 1,8 & 14,8 \\
\hline Toronto & Canada & 2,8 & 12 \\
\hline Bangalore & India & 11 & 10 \\
\hline Santiago & Chile & 7,3 & 9,6 \\
\hline Seoul & South Korea & 10,3 & 5,1 \\
\hline Taiwan & China & 1,9 & 4,2 \\
\hline Paris & France & 2,3 & 100 \\
\hline \multicolumn{4}{|c|}{ Designed } \\
\hline Pena Station Next & USA & Saudi Arabia & 100 \\
\hline Queyside & \multicolumn{1}{|c|}{}
\end{tabular}

The processes and technological directions of development of renewable and in particular solar energy considered by us indicate dynamics of an investment stream (Table 2).

Table 2. Status of investment flow in renewable energy during 2009-2019, billion dollars USA.

\begin{tabular}{|c|c|c|c|c|c|c|c|c|c|c|}
\hline $\begin{array}{c}\text { Type of } \\
\text { renewable } \\
\text { energy }\end{array}$ & 2010 & 2011 & 2012 & 2013 & 2014 & 2015 & 2016 & 2017 & 2018 & 2019 \\
\hline Wind & 97,8 & 83,3 & 8,3 & 3,3 & 11,1 & 19,7 & 23,5 & 33,4 & 32,7 & 42,7 \\
\hline Solar & $\mathbf{1 0 2 , 0}$ & $\mathbf{1 6 0 , 1}$ & $\mathbf{1 4 4 , 0}$ & $\mathbf{1 2 0 , 4}$ & $\mathbf{1 4 7 , 8}$ & $\mathbf{1 7 6 , 6}$ & $\mathbf{1 4 5 , 9}$ & $\mathbf{1 8 0 , 8}$ & $\mathbf{1 4 3 , 5}$ & $\mathbf{1 4 0 , 0}$ \\
\hline Biomass & 17,3 & 20,9 & 15,4 & 14,6 & 13,1 & 10,4 & 15,2 & 7,4 & 11,5 & 11,2 \\
\hline Biogas & 10,1 & 10,5 & 7,7 & 5,1 & 5,5 & 3,6 & 2,1 & 3,3 & 3,3 & 3,0 \\
\hline $\begin{array}{c}\text { Hydrogen } \\
\text { up to 50 } \\
\text { watts) }\end{array}$ & 8,2 & 7,7 & 6,3 & 5,7 & 7,4 & 4,2 & 4,3 & 4,0 & 2,3 & 2,5 \\
\hline $\begin{array}{c}\text { Geothermal } \\
\text { Oceanic }\end{array}$ & 2,8 & 3,8 & 1,7 & 2,4 & 2,9 & 2,5 & 2,7 & 2,4 & 2,5 & 1,2 \\
\hline Total & 238,5 & 28,3 & 0,3 & 0,2 & 0,4 & 0,2 & 0,2 & 0,2 & 0,2 & 0,2 \\
\hline
\end{tabular}

Solar energy remains the main object of investment for 10 years, followed by wind energy. This provision is explained by the priority development of the control system of stations and their processes with the involvement of automated modules of artificial intelligence and the elimination at the legislative level of restrictions on connection to the existing transmission line network. 
The investment market for renewable energy has been set at $\$ 300$ billion, and the solar market at $\$ 143$ billion. The share of investment in solar energy is actually $50 \%$ [10]. The tendency to reduce them is due to the review state of the world economy and the problems of the financial and credit system, which is manifested in the general trend of growing debt.

The dynamics of investment in solar energy reflects the intensive growth of the flow of investment from 2009 to 2015. In 2016, there is a sharp decline. In 2017, investment resumed and amounted to 180.8 billion dollars. From 2018, there is a clear trend to reduce investment income in solar energy. Such dynamics indicate a change in the investment climate in this energy sector, as well as a change in the external environment, when a large number of external and national financial resources began to be directed to overcome the pandemic of coronary heart disease COVID-2019.

Considering the investment processes of renewable energy, we note the change in the share of investment in solar energy (Fig. 1). The dynamics of changes in the rate of investment in solar energy during 2009-2019 reflects the declining nature with short-term cyclical decline and growth. The long-term nature of the decline is determined by the intensive development of technical and technological maintenance of solar energy, which leads to a decrease in the profitability of the industry, which is reflected in lower prices for components and equipment. Short-term cyclical fluctuations are the result of the system of state regulation of this industry (preferential tariff system, preferential lending).

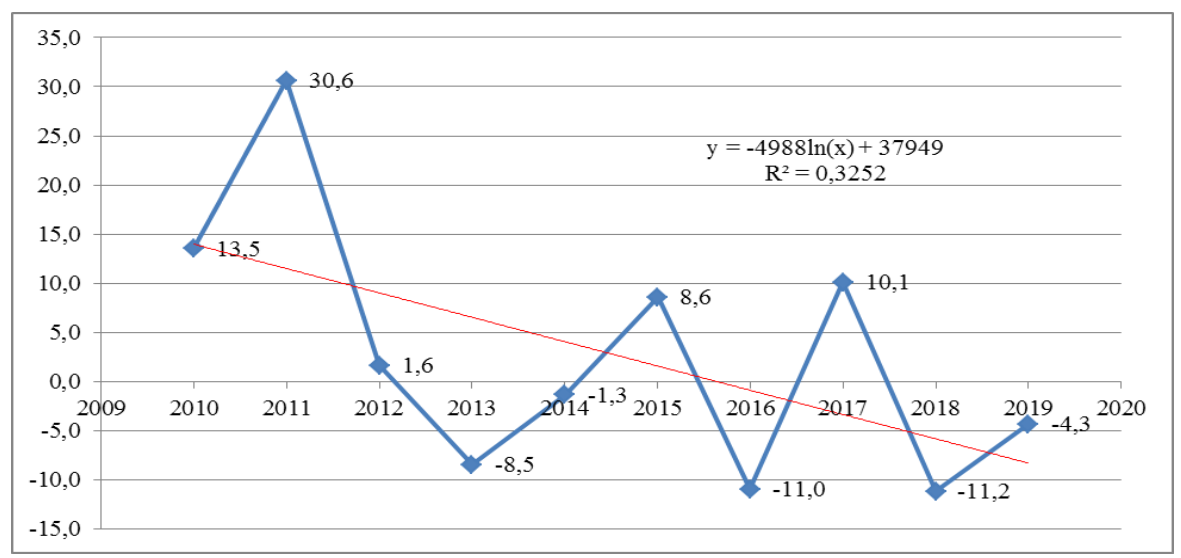

Fig. 1. Dynamics of changes in the pace of global investment in solar energy, 2009-2019, \%.

The main tool for investing in solar energy for China is the budget financing of largescale solar power plants. However, the budget debt burden from 2019 has led to a revision of subsidies for renewable energy, including solar. Therefore, from 2020, budget subsidies will be abolished, remaining only for centralized stations with a capacity of up to $1 \mathrm{MW}$. From 2021, state subsidies will not be received by wind farms. In addition, from 2021, budget funds to support renewable energy will be reduced by 1.04 billion euros. At the same time, in 2019 such a reduction amounted to 0.73 million euros. As of 2020, subsidies to solar stations amounted to only 2.63 billion yuan. This trend in reducing solar energy investment, in addition to China, is typical for Europe and the United States.

Since 2011, the French company Ciel \& Terre has developed a solar system Hydrelio Floating PV (floating island) [11]. This system has become widely used in Chile and Japan. The first floating solar platform (112 sq.m.) was created in Chile, financed by private companies from England and the United States [12].

In Egypt, since 2019, the world's largest solar station Benban Solar Park worth \$ 823 million, with a capacity of 1.6-2 GW [13]. 
This project is specific in that the government did not provide its funding, but signed an agreement for a period of 20 years, according to which it will buy electricity at 7-8 cents per $1 \mathrm{~kW}$. In fact, it is a comprehensive financial model for the implementation of solar stations, in which government support allows private investment groups to implement large-scale projects at affordable prices. In particular, political risk insurance is provided in the amount of USD 210 million. private lenders and investors involved in the expansion of the park.

Private investment in solar energy is aimed at increasing solar panels. In particular, the British company Lightsource BP returned to the production of solar panels, buying a $43 \%$ stake worth \$200 million the largest European company for the production of solar companies [14]. In addition, the information company Google in 2017 invested \$ 3.5 billion in renewable energy. and announced a complete transition to renewable energy [15-17].

A tool for investing in solar stations proved to be effective. In particular, at the end of 2019, the Hevel group of companies and the Eurasian Development Bank signed a loan agreement to open a long-term multi-credit line of 65.2 million euros to finance the construction of a $100 \mathrm{MW}$ solar station in Kazakhstan.

A separate option for investing corporate capital is the purchase agreement of solar station. At the same time, such investment is carried out under the condition that the renewable energy source (RES) will increase the additional capacity of the station [18-20]. Those who initiate such agreements are companies that actively manage the purchase of electricity and its distribution, and such an item in their costs is quite significant [21-25]. In fact, these purchases are made by companies in which electricity costs exceed $15 \%$ of their operating costs. Therefore, such investment was unattractive for small private companies in the corporate market [23-32]. This tool provides additional benefits and significant savings compared to PPS, the «green tariff», and compared to traditional power plants. Accordingly, the solar energy market is conventionally divided into sectors (Table 3 ).

Table 3. Market structure of solar energy in relation to investment instruments.

\begin{tabular}{|l|l|}
\hline \multicolumn{1}{|c|}{ Investment tool } & \multicolumn{1}{|c|}{ National economies } \\
\hline Solar power plants & $\begin{array}{l}\text { China, Colombia, Croatia, Cyprus, Guatemala, Honduras, Israel, } \\
\text { Malaysia, Malta, Philippines, Romania, Saudi Arabia, } \\
\text { Switzerland, Turkey, Uganda }\end{array}$ \\
\hline $\begin{array}{l}\text { Solar power plants + «green» } \\
\text { tariff }\end{array}$ & $\begin{array}{l}\text { Bulgaria, Czech Republic, Estonia, Greece, Hungary, Japan, } \\
\text { Latvia, Lithuania, Luxembourg, Poland, Korea, Singapore, } \\
\text { Slovakia, Slovenia, South Africa, Spain, Ukraine }\end{array}$ \\
\hline $\begin{array}{l}\text { Solar power plants + purchase } \\
\text { agreement }\end{array}$ & Brazil, Chile, Jordan \\
\hline $\begin{array}{l}\text { Solar power plants + purchase } \\
\text { agreement + «green» tariff }\end{array}$ & $\begin{array}{l}\text { Australia, Italy, Austria, Mexico, Belgium, Netherlands, Canada, } \\
\text { Norway, Denmark, Portugal, Finland }\end{array}$ \\
\hline $\begin{array}{l}\text { purchase agreement + «green» } \\
\text { tariff }\end{array}$ & Morocco \\
\hline purchase agreement & $\begin{array}{l}\text { Algeria, Argentina, Burkina Faso, Egypt, Eritrea, Ghana, Kenya, } \\
\text { Namibia, New Zealand, Panama }\end{array}$ \\
\hline «Green» tariff & South Sudan \\
\hline
\end{tabular}

Source: formed the authors based on [16].

In general, Chinese scientists have proved the following regularity in terms of energy investment on an annual basis [17]:

$$
C(t)=C 0^{*} N(t) \phi^{*} e \mu(t)
$$

where $\mathrm{C}(\mathrm{t})$ - investment costs per unit of energy in a given year; $\mathrm{C} 0$ - investment costs per unit of energy in the base year; $\mathrm{N}(\mathrm{t})$ - the set of installed capacity in the current year; $\phi-$ coefficient of elasticity; $\mu$-random factor. 
In this case, the determining factor is the coefficient of elasticity for total production:

$$
\text { LR(learning rate) }=1-2 \phi
$$

Technological diffusion is a function of the dependence of the maximum possible volume of the installed capacity on the level of technological development in the considered period of time. Within the theory of diffusion of innovations, there are 3 stages of technologically renewable energy: a long period of slow growth, rapid leap and reaching the limit value.

In addition, the estimate of the maximum volume of the installed capacity of solar stations is calculated depending on the level of technological development through technological diffusion:

$$
\mathrm{dM}(\mathrm{t}) / \mathrm{dt}=\mathrm{f}(\mathrm{t})\{\mathrm{m}-\mathrm{M}(\mathrm{t})\}
$$

$\mathrm{M}(\mathrm{t})$ - the maximum possible amount of installed capacity, $\mathrm{m}$ - theoretically possible maximum installed power, $\mathrm{f}(\mathrm{t})$ - time dependence function.

Based on the basic formulas, the calculation indicates that within ten years the production of solar electricity will be comparable in cost to the cost of electricity production of nuclear electricity.

\section{Conclusions}

Summing up the results of the study, we note that solar energy is an attractive area of international investment, the share of which in renewable energy reaches almost $50 \%$. The main investment flows come through private investors, which are large international companies. It should be noted that the share of investments from venture funds as of the end of 2019 decreased. This is due to the changing environment, when most financial flows were directed to the mass vaccination of the world's population (due to the COVID-2019 pandemic crown viral disease). Such investment flows ensure the development of large projects that have reached the stage of solar parks. For small solar power plants, investing is a priority for households. This niche is dominated by Australia. Such investment is a reaction to the increase in tariffs for end users of electricity.

A significant factor in investing in solar energy is its state support. It is due to the legislative delineation of this area and the consolidation of relevant programs (prioritylong-term) that a favorable investment climate is formed, which allows foreign private capital to confidently enter national markets and implement large-scale projects. Among such countries that create a favorable investment climate, China holds the lead. Among the developing countries that have succeeded are Chile and Ukraine. Chile has been forced to introduce alternative energy due to its relatively low-capacity energy sector and large electricity exports. And Ukraine has secured this position by lobbying for legislative initiatives in the interests of Ukrainian oligarchs.

The general trend is to reduce energy investment, including solar. This is due to the fact that the crisis in the global debt market is intensifying, which has an impact on public financial regulation and corporate investment expenditures in the direction of reduction. From the technological approach there is a reduction in cost and simplification of the most innovative technologies, which is not attractive for venture investors. There is a tendency to reduce the level of the green tariff, which was quite attractive to investors.

Thus, there is a general economic pattern, which notes that renewable energy, including solar, is entering the stage of traditional end-of-life business, and venture capital is focused on innovative development of energy saving and renewable energy management as a single energy system along with traditional ones. The tools for investing in solar energy are guaranteed state funding, which determines the priority of its development by country and guaranteed cash flow of investments through the payment of the green tariff. 
However, globally, the level of investment in solar energy is determined by the dynamics of lending. This explains the decline in investment since 2018 due to the escalation of the global debt crisis as a consequence of overcoming the economic crisis of 2007-2008. Theoretically, the basic factor of investing in renewable energy is highlighted this energy is not resource-intensive by nature, because natural resources are renewable and completely separated from the market value. Therefore, its development, including solar energy, depends solely on the capital intensity of technologies and technical and organizational solutions.

\section{References}

1. REN21 (2020). Renewable Global Status Report. https://www.ren21.net/wpcontent/uploads/2019/05/gsr_2020 full_report_en.pdf

2. SAEE (2016). Renewables Global Status Report.https://saee.gov.ua/sites/default/files/GSR_2016_Full_Report.pdf

3. International Energy Agency. (2021) Photovoltaic Power Systems Programme. https://iea-pvps.org/snapshot-reports/snapshot-2020

4. IRENA (2020). Renewable Capacity Statistics. https://www.irena.org/publications/2020/Mar/Renewable-Capacity-Statistics-2020

5. IRENA (2020). Energy subsidies: Evolution in the global energy transformation to 2050 https://www.irena.org/publications/2020/Apr/Energy-Subsidies-2020

6. IRENA: Global solar months away from sweeping grid parity (2019). https://www.pvtech.org/irena-global-solar-months-away-from-sweeping-grid-parity

7. IEA (2020) Energy Prices 2020. High-quality data on end-use energy prices. https://www.iea.org/reports/energy-prices-2020\#data-service

8. First Solar (2021). Leading the World's Sustainable Energy Future. https://www.firstsolar.com/en-Emea/

9. Renewablesnow (2017). Saudi Arabia plans USD-500bn renewables-powered economic zone. https://renewablesnow.com

10. Solarreviews (2020). Investing in solar energy: What return can you get on your solar investment? https://www.solarreviews.com/blog/investing-in-solar-energy-what-returncan-you-get-on-your-solar-investment

11. CIEL (2021). Hydrelio: the Patented Floating PV System. https://www.ciel-etterre.net/hydrelio-floating-solar-technology/hydrelio-products

12. Smart-energy (2019). Chile tests floating solar power island. https://www.smartenergy.com/industry-sectors

13. Nsenergybusiness (2021).

Benban

Solar

Park. https://www.nsenergybusiness.com/projects/benban-solar-park

14. Lightsourcebp (2021). Solar power for our world. https://www.lightsourcebp.com

15. The Guardian (2017). Google to be powered $100 \%$ by renewable energy from 2017. https://www.theguardian.com/environment/2016

16. International Renewable Energy Agency (2018). Corporate Sourcing of Renewables: Market and Industry Trends - REmade Index 2018. https://static1.squarespace.com

17. Cong, Rong-Gang (2013). An optimization model for renewable energy generation and its application in China: A perspective of maximum utilization. Renewable and Sustainable Energy Reviews, Elsevier, 17(C), 94-103. https://doi.org/10.1016/j.rser.2012.09.005 
18. Yankovyi, O., Goncharov, Yu., Koval, V., \& Lositska, T. (2019). Optimization of the capital-labor ratio on the basis of production functions in the economic model of production. Naukovyi Visnyk Natsionalnoho Hirnychoho Universytetu, 4, 134-140.

19. Baklanova, O., Petrova, M., \& Koval, V. (2020). Institutional Transmission in Economic Development. Ikonomicheski Izsledvania, 29(1), 68-91.

20. Hutsaliuk, O., Koval, V., Tsimoshynska, O., Koval, M., Skyba, H. (2020). Risk Management of Forming Enterprises Integration Corporate Strategy. TEM Journal, 9(4), 1514-1523. https://doi.org/10.18421/TEM94-26

21. Bilan, Y., Nitsenko, V., \& Havrysh, V. (2017). Energy aspect of vertical integration in agriculture. Rynek Energii, 5(132), 98-110.

22. Dankeieva, O., Solomianiuk, N., Strashynska, L., Fiedotova, N., Soloviova, Y., \& Koval, V. (2021). Application of Cognitive Modelling for Operation Improvement of Retail Chain Management System. TEM Journal, 10(1), 358-367. https://doi.org/10.18421/TEM101-45

23. Shmygol, N., Schiavone, F., Trokhymets, O., Pawliszczy, D., Koval, V., Zavgorodniy, R., \& Vorfolomeiev A. (2020). Model for assessing and implementing resourceefficient strategy of industry. CEUR Workshop Proceedings, 2713, 277-294.

24. Amer, M., \& Daim, T. U. (2010). Application of technology roadmaps for renewable energy sector. Technological forecasting and social change, 77(8), 1355-1370.

25. Koval, V., Sribna, Y.,\& Gaska, K. (2019). Energy cooperation Ukraine-Poland to strengthen energy security. E3S Web Conference, 132, 01009. https://doi.org/10.1051/e3sconf/201913201009

26. Ciuła, J., Gaska, K., Siedlarz, D., \& Koval, V. (2019). Management of sewage sludge energy use with the application of bi-functional bioreactor as an element of pure production in industry. E3S Web Conference, 123, 01016. https://doi.org/10.1051/e3sconf/201912301016

27. Jacobsson, S., \& Bergek, A. (2004). Transforming the energy sector: the evolution of technological systems in renewable energy technology. Industrial and corporate change, 13(5), 815-849.

28. Koval, V., Sribna, Y., Mykolenko, O., \& Vdovenko, N. (2019). Environmental concept of energy security solutions of local communities based on energy logistics. 19th International Multidisciplinary Scientific GeoConference SGEM 2019, 19(5.3), 283290. https://doi.org/0.5593/sgem2019/5.3/S21.036

29. Nitsenko, V., Mardani, A., Streimikis, J., Shkrabak, I., Klopov, I., Novomlynets, O., \& Podolska, O. (2018). Criteria for Evaluation of Efficiency of Energy Transformation Based on Renewable Energy Sources. Montenegrin Journal of Economics, 14(4), 253263. https://doi.org/10.14254/1800-5845/2018.14-4.17

30. Kalinichenko, A., Havrysh, V., \& Nitsenko, V. (2019). Alternative Vehicle Fuel Management: Impact on Energy Security Indicators. In: Krakowiak-Bal A., Vaverkova M. (eds) Infrastructure and Environment. Springer, Cham, 367-374.

31. Saik, P., Petlevanyi, M., Lozynskyi, V., Sai, K., \& Merzlikin, A. (2018). Innovative approach to the integrated use of energy resources of underground coal gasification. Solid State Phenomena, (277), 221-231. https://doi.org/10.4028/www.scientific.net/SSP.277.221

32. Thiam, D. R. (2011). An energy pricing scheme for the diffusion of decentralized renewable technology investment in developing countries. Energy Policy, 3, 4284-4297. 